\title{
PENGARUH BELANJA KEGIATAN INTENSIFIKASI PENDAPATAN ASLI DAERAH (PAD) TERHADAP PENERIMAAN PENDAPATAN ASLI DAERAH (PAD) PADA DINAS PENDAPATAN DAERAH KOTA CIMAHI
}

\author{
Lilis Karnita Soleha
}

\begin{abstract}
ABSTRAK
Dalam menjamin terselenggaranya otonomi daerah yang tangguh, diperlukan usaha-usaha yang dilakukan oleh pemerintah daerah dalam rangka peningkatan PAD antara lain peningkatan cakupan ekstensifikasi dan intensifikasi PAD. Penelitian ini bertujuan untuk menganalisis pengaruh belanja kegiatan intensifikasi Pendapatan Asli Daerah (PAD) terhadap penerimaan Pendapatan Asli Daerah (PAD) pada Dinas Pendapatan Daerah Kota Cimahi.

Hasil yang diperoleh adalah Belanja Kegiatan Intensifikasi Pendapatan Asli Daerah (PAD) sangat berpengaruh terhadap peningkatan PAD di Kota Cimahi. Hal ini didukung oleh uji statistik, dimana $r=0,847$ menunjukan adanya korelasi linier antar variabel. Koefisien Determinasinya $71,8 \%$ mengindikasikan bahwa pengaruh $X$ terhadap $Y$ kuat, dimana $71,8 \%$ variasi nilai PAD di Kota Cimahi disebabkan oleh karena adanya perbedaan dalam nilai Belanja Kegiatan Intensifikasi PAD di Kota Cimahi, hal ini menunjukan bahwa ada pengaruh Belanja Kegiatan Intensifikasi PAD terhadap PAD di Kota Cimahi. Sehingga dapat disimpulkan bahwa semakin besar belanja kegiatan intensifikasi Pendapatan. Asli Daerah (PAD) yang dikeluarkan maka semakin besar pula penerimaan Pendapatan Asli Daerah (PAD) yang akan diterima.
\end{abstract}

Keyword: Kegiatan Intensifikasi Pendapatan Asli Daerah, Peningkatan PAD

\section{LatarBelakang}

Pemerintahan merupakan suatu organisasi yang dibentuk oleh suatu negara yang diberi kekuasaan untuk menjalankan tugas dan kepentingan negara. Maka dari itu pemerintahan di suatu negara memegang peranan penting dalam pembangunan nasional. Sebab pemerintahan merupakan salah satu perantara aspirasi rakyat yang harus mampu mengelola dan menjalankan tugasnya dengan baik, salah satunya untuk menciptakan pembangunan nasional secara optimal dan merata. Pembangunan nasional tidak hanya mencakup di pemerintahan pusat saja, tetapi juga harus merata sampai ke tingkat daerah. Karena dengan pembangunan daerah yang lebih baik maka akan mendatangkan atau menghasilkan pendapatan yang lebih baik pula bagi pemerintahan daerah dan pemerintahan daerah.

Penyelenggaraan pemerintahan daerah merupakan salah satu amanat dari peraturan perundang-undangan yang harus dilaksanakan secara baik, bersih, dan bertanggungjawab. Dalam rangka mewujudkan pemerintahan yang baik (good governance) pemerintah daerah harus mengedepankan beberapa aspek antara lain adanya tranparansi, akuntabilitas, efektifitas dan efisiensi, menjunjung tinggi supremasi hukum serta melibatkan partisipasi masyarakat.

Sebagai daerah otonom, pemerintah mempunyai wewenang dan tanggungjawab dalam menyelenggarakan kegiatannya untuk memenuhi kebutuhan dan kepentingan masyarakat berdasarkan prinsip keterbukaan dengan melibatkan partisipasi masyarakat dan mempunyai tanggung jawab kepada masyarakat. Dengan diberlakukannya UU No. 32 Tahun 2004 tentang Peraturan Daerah sebagaimana telah diubah beberapa kali terakhir dengan Undang-Undang Nomor 12 Tahun 2008 tentang perubahan kedua atas Undang-Undang Nomor 32 Tahun 2004 tentang Pemerintahan Daerah, menyarankan bahwa wilayah daerah merupakan daerah otonom yang harus berupaya semaksimal mungkin untuk mengatur, mengelola, dan membiayai rumah tangganya sendiri di daerahnya masing-masing.
Penyelenggaraan otonomi daerah harus berorientasi pada peningkatan kesejahteraan masyarakat dengan selalu memperhatikan kepentingan dan aspirasi yang tumbuh dalam masyarakat. Dan otonomi daerah juga harus mampu menjamin hubungan yang serasi antara pemerintah daerah dan pusat. Tujuan otonomi daerah adalah menciptakan efisiensi dan efektifitas pengelolaan sumberdaya daerah, meningkatkan kualitas pelayanan umum, membudayakan dan menciptakan ruang bagi masyarakat untuk ikut serta berpartisipasi dalam proses pembangunan (Yowono, 2005:50).

Dengan adanya otonomi daerah ini maka pemerintah daerah dituntut untuk berusaha agar menggali potensi yang dimiliki daerahnya sehingga dapat menghasilkan pendapatan daerah yang maksimal. Besar kecilnya pendapatan daerah sangat mempengaruhi kemajuan pembangunan di daerah tersebut, karena dengan otonomi daerah pemerintah daerah tidak lagi bergantung pada pemerintah pusat, tetapi tergantung pada kemampuan daerah tersebut untuk menggali sumber daya dan memanfaatkannya semaksimal mungkin.

Dalam pelaksanaan otonomi daerah, yang menjadi sumber utama bagi daerah adalah Pendapatan Asli Daerah (PAD). Pendapatan Asli Daerah meliputi Pajak Daerah, Retribusi Daerah, Hasil Bumi dan Pengelolaan Kekayaan Daerah serta Pendapatan lainnya.

Berdasarkan penelitian yang dilakukan oleh Horasman pada tahun 2003, penerimaan daerah yang paling dominan di Kota Cimahi bersumber dari dana perimbangan (dana dari Pemerintah Pusat). Pendapatan Asli Daerah (PAD) masih memiliki peran yang relative kecil dalam struktur keuangan daerah, sehingga masih bergantung terhadap transfer dari Pemerintahan pusat. Hal senada dikatakan oleh Lestari (2005), bahwa Kota Cimahi masih ketergantungan terhadap bantuan dari pemerintah pusat, hal ini terbukti dengan kecilnya penerimaan PendapatanAsli Daerah (PAD) Kota Cimahi dan besarnya penerimaan dari dana perimbangan. 
Dengan demikian dapat dikatakan bahwa penerimaan Pemerintah Kota Cimahi dominannya bersumber dari Pemerintah Pusat.
Untuk mengetahui lebih jelas dapat dilihat pada tabel-tabel dibawah ini.

Struktur Pendapatan Kota Cimahi Tahun 2002 - 2011

\begin{tabular}{|c|c|c|}
\hline TAHUN & URAIAN & PENDAPATAN (Rp) \\
\hline \multirow{4}{*}{2002} & 1. PAD & 25.750 .017 .455 \\
\hline & 2. Dana Perimbangan & 114.619 .968 .850 \\
\hline & 3. Lain-lain Pendapatan yang sah & 11.389 .808 .000 \\
\hline & Jumlah & 151.759 .794 .305 \\
\hline \multirow{4}{*}{2003} & 1.PAD & 29.488 .458 .866 \\
\hline & 2. Dana Perimbangan & 180.327 .023 .000 \\
\hline & 3. Lain-lain Pendapatan yang sah & 15.025 .000 .000 \\
\hline & Jumlah & 224.840 .481 .866 \\
\hline \multirow{4}{*}{2004} & 1. PAD & 41.152 .294 .199 \\
\hline & 2. Dana Perimbangan & 202.182 .417 .537 \\
\hline & 3. Lain-lain Pendapatan yang sah & 9.999 .751 .000 \\
\hline & Jumlah & 253.334 .462 .736 \\
\hline \multirow{4}{*}{2005} & 1. PAD & 48.242 .903 .314 \\
\hline & 2. Dana Perimbangan & 210.917 .229 .975 \\
\hline & 3. Lain-lain Pendapatan yang sah & 15.950 .000 .000 \\
\hline & Jumlah & 275.110 .113 .289 \\
\hline \multirow{4}{*}{2006} & 1. PAD & 51.646 .055 .859 \\
\hline & 2. Dana Perimbangan & 308.779 .317 .345 \\
\hline & 3. Lain-lain Pendapatan yang sah & 18.051 .000 .000 \\
\hline & Jumlah & 378.476 .373 .204 \\
\hline \multirow{4}{*}{2007} & 1. PAD & 55.813 .859 .454 \\
\hline & 2. Dana Perimbangan & 333.948 .767 .156 \\
\hline & 3. Lain-lain Pendapatan yang sah & 55.939 .260 .728 \\
\hline & Jumlah & 445.701 .887 .338 \\
\hline \multirow{4}{*}{2008} & 1. PAD & 65.108 .137 .872 \\
\hline & 2. Dana Perimbangan & 385.339 .766 .618 \\
\hline & 3. Lain-lain Pendapatan yang sah & 51.431 .328 .523 \\
\hline & Jumlah & 501.879 .233 .013 \\
\hline \multirow{4}{*}{2009} & 1. PAD & 74.383 .053 .802 \\
\hline & 2. Dana Perimbangan & 415.077 .394 .467 \\
\hline & 3. Lain-lain Pendapatan yang sah & 49.025 .642 .427 \\
\hline & Jumlah & 538.486 .090 .696 \\
\hline \multirow{4}{*}{2010} & 1. PAD & 87.321 .034 .057 \\
\hline & 2. Dana Perimbangan & 432.570 .291 .521 \\
\hline & 3. Lain-lain Pendapatan yang sah & 99.597 .512 .151 \\
\hline & Jumlah & 619.488 .837 .729 \\
\hline \multirow{4}{*}{2011} & 1. PAD & 117.928 .288 .161 \\
\hline & 2. Dana Perimbangan & 422.164 .126 .956 \\
\hline & 3. Lain-lain Pendapatan yang sah & 182.904 .861 .668 \\
\hline & Jumlah & 722.997 .276 .785 \\
\hline
\end{tabular}


Berikut struktur Pendapatan Kota Cimahi dibandingkan dengan Pendapatan Asli Daerah Kota Cimahi :

Tabel 2

Kontribusi PAD Kota Cimahi

Tahun $2002-2011$

\begin{tabular}{|c|c|c|c|}
\hline TAHUN & TOTAL PENDAPATAN & JUMLAH PAD & KONTRIBUSI PAD \\
\hline 2002 & 150.115 .532 .850 & 25.750 .017 .455 & $17,15 \%$ \\
\hline 2003 & 256.573 .107 .200 & 29.488 .458 .866 & $11,49 \%$ \\
\hline 2004 & 245.356 .565 .068 & 41.152 .294 .199 & $16,77 \%$ \\
\hline 2005 & 270.227 .010 .447 & 48.242 .903 .314 & $17,85 \%$ \\
\hline 2006 & 378.752 .271 .569 & 51.646 .055 .859 & $13,64 \%$ \\
\hline 2007 & 445.701 .887 .338 & 55.813 .859 .454 & $12,52 \%$ \\
\hline 2008 & 501.879 .233 .013 & 65.108 .137 .872 & $12,97 \%$ \\
\hline 2009 & 538.486 .090 .696 & 74.383 .053 .802 & $13,81 \%$ \\
\hline 2010 & 619.488 .837 .729 & 87.321 .034 .057 & $14,10 \%$ \\
\hline 2011 & 722.997 .276 .785 & 117.928 .288 .161 & $16,31 \%$ \\
\hline
\end{tabular}

Sumber :DinasPendapatan Daerah Kota Cimahi (diolah)

Dari tabel diatas kita dapat mengetahui Pendapatan Asli Daerah (PAD) Kota Cimahi berkontribusi kecil terhadap Total Pendapatan Kota Cimahi jika kita bandingkan dengan jumlah Pendapatan Daerah, artinya pembiayaan kegiatan Kota Cimahi masih bergantung pada bantuan pusat. Hal tersebut tentu saja berdampak negative terhadap kegiatan-kegiatan yang ada di Kota Cimahi, seperti tersendatnya belanja kegiatan disetiap SKPD serta tersendatnya kegiatan pembangunan daerah.

Pemerintah Kota Cimahi sampai saat ini masih mendapatkan kebijakan dari Pemerintah Pusat, pada Dana Perimbangan yang seharusnya membiayai kegiatan-kegiatan penggajian Pegawai Negeri Sipil Daerah (PNSD), sebagian dari itu dialokasikan untuk membantu kelancaran kegiatan belanja daerah. Sesuai dengan yang diungkap oleh E. Koswara dalam Abdul Halim (2004:35) bahwa :

"Ciri utama yang menunjukkan suatu daerah otonom mampu berotonomi terletak pada kemampuan keuangan daerah artinya daerah otonom harus memiliki kewenangan dan kemampuan untuk menggali sumber keuangan sendiri, sedangkan ketergantungan kepada bantuan pemerintah pusat harus seminimal mungkin, sehingga Pendapatan Asli Daerah (PAD) harus menjadi bagian sumber keuangan terbesar yang didukung oleh kebijakan pembagian keuangan pusat dan daerah sebagai masyarakat sistem pemerintahan negara."

Dari pernyataan diatas berbanding terbalik dengan keadaan di Pemerintah Kota Cimahi yang pada saat ini masih mendapat kebijakan dari pemerintah pusat berupa bantuan dalam bentuk pengalokasian sebagian dari Dana Perimbangan dengan jumlah yang begitu besar dan dinilai menjadi sebuah ketergantungan. Maka dalam hal ini Pemerintah Kota Cimahi harus berupaya lebih untuk meningkatkan Pendapatan Asli Daerah.

Dalam upaya meningkatkan Pendapatan Asli Daerah (PAD) pada dasarnya dapat ditempuh melalui beberapa upaya, salah satu diantaranya yaitu dengan cara Intensifikasi Pendapatan Asli Daerah (PAD). Intensifikasi Pendapatan Asli Daerah (PAD) merupakan suatu upaya memperbesar penerimaan dengan cara melakukan pemungutan lebih giat, ketat dan teliti melalui pajak daerah, retribusi daerah, hasil pengelolaan kekayaan daerah yang dipisahkan dan lain-lain Pendapatan Asli Daerah (PAD) yang sah.

Upaya Pemerintah Kota Cimahi dalam Intensifikasi Pendapatan Asli Daerah (PAD) maka diadakan alokasi dana untuk kelancaran kegiatan tersebut. Untuk mendukung tujuan tersebut Pemerintah Kota Cimahi mengaplikasikannya kepada beberapa program dan Kegiatan Intensifikasi Pendapatan diantaranya :

1. Penerimaan Bagi Hasil Pajak dan Bagi Hasil Bukan Pajak;

2. Peningkatan Penerimaan PBB;

3. Peningkatan Administasi Pelayanan Pajak Daerah:

4. Optimalisasi Penerimaan Pajak Daerah;

5. Pembinaan dan Penyuluhan Pajak Daerah dan Retribusi Daerah;

6. Peningkatan Kepatuhan Perpajakan;

7. Pengawasan Penerimaan PAD.

Hal ini tentu saja sangat mendukung, karena dengan adanya kegiatan intensifikasi yang berjalan dengan baik diharapkan dapat meningkatkan pendapatan daerah serta mengurang ketergantungan kepada pemerintah pusat, dan Pemerintah Kota Cimahi dapat mensejahterakan kehidupan rakyat. 


\section{Kerangka Berfikir}

Di era otonomi daerah yang dimulai digulirkan melalui Undang-Undang Nomor 22 Tahun 1999 tentang Pemerintahan Daerah, sebagaimana telah diganti dengan Undang-Undang Nomor 32 Tahun 2004 tentang Pemerintahan Daerah, setiap daerah diberikan hak untuk menyelenggarakan otonomi daerah dengan kewenangan yang luas, nyata dan bertanggung jawab yang dapat menjamin perkembangan dan pembangunan daerah.

Untuk menyelenggarakan otonomi daerah yang luas, nyata dan bertanggung jawab sangat diperlukan dukungan anggaran yang memadai, yang salah satunya harus dipenuhi oleh Pendapatan Asli Daerah (PAD) yang optimal. Dalam menjamin terselenggaranya otonomi daerah yang tangguh, maka diperlukan pula usaha-usaha yang dilakukan oleh pemerintah daerah dalam rangka peningkatan PAD antara lain peningkatan cakupan ekstensifikasi dan intensifikasi PAD.
Ada tiga hal penting yang harus diperhatikan dalam usaha peningkatan cakupan ini, yaitu : (1) menambah objek dan subjek pajak dan atau retribusi, (2) meningkatkan besarnya penetapan, (3) mengurangi tunggakan.

Variabel yang paling mungkin dilakukan pengujian korelasional dengan PAD adalah varibel intensifikasi PAD, dengan alasan Intensifikasi PAD mempunyai jenis data yang sama dengan PAD, yaitu kuantitatif dan skala construct yang sama dengan PAD, yaitu skala rasio. Oleh karena itu dalam penelitian ini, penulis memilih Intensifikasi $P A D$ sebagai variabel Independen $(X)$ yang akan diuji derajat korelasionalnya terhadap Pendapatan Asli Daerah (Y).

\section{Operasionalisasi Variabel}

Variabel-variabel yang digunakan dalam penelitian ini dijabarkan dalam tabel sebagai berikut

Tebel 3

Operasionalisasi Variabel

\begin{tabular}{|c|c|c|c|}
\hline VARIABEL & KONSEP VARIABEL & INDIKATOR & SKALA \\
\hline $\begin{array}{l}\text { Belanja kegiatan } \\
\text { Intensifikasi PAD } \\
(X)\end{array}$ & $\begin{array}{l}\text { Belanja Kegiatan Intensifikasi } \\
\text { Pendapatan Asli Daerah (PAD) } \\
\text { merupakan penurunan kas } \\
\text { pemerintah untuk pembayaran } \\
\text { suatu tindakan atau usaha-usaha } \\
\text { (pemungutan yang lebih giat, } \\
\text { ketat dan teliti) dengan tujuan } \\
\text { memperbesar penerimaan } \\
\text { Pendapatan Asli Daerah (PAD). }\end{array}$ & $\begin{array}{l}\text { Besarnya belanja } \\
\text { kegiatan } \\
\text { Intensifikasi } \\
\text { Pendapatan Asli } \\
\text { Daerah (PAD) } \\
\text { tahun } 2002 \text { s/d } \\
\text { tahun } 2011\end{array}$ & $\begin{array}{l}R \\
A \\
S \\
1 \\
0\end{array}$ \\
\hline $\begin{array}{l}\text { Pendapatan Asli } \\
\text { Daerah (PAD) } \\
\text { (Y) }\end{array}$ & $\begin{array}{l}\text { Pendapatan Asli Daerah (PAD) } \\
\text { adalah penerimaan yang } \\
\text { diperoleh daerah dari sumber- } \\
\text { sumber dalam wilayahnya sendiri } \\
\text { yang dipungut berdasarkan } \\
\text { peraturan daerah sesuai dengan } \\
\text { peraturan perundang-undangan } \\
\text { yang berlaku }\end{array}$ & $\begin{array}{l}\text { Besarnya } \\
\text { Pendapatan Asli } \\
\text { Daerah (PAD) } \\
\text { tahun } 2002 \text { s/d } \\
\text { tahun } 2011\end{array}$ & $\begin{array}{l}R \\
A \\
S \\
1 \\
O\end{array}$ \\
\hline
\end{tabular}

\section{Hasil dan Pembahasan}

4.1. Jumlah Belanja Kegiatan Intensifikasi Pendapatan Asli Daerah (PAD) di Kota Cimahi

Belanja Kegiatan Intensifikasi Pendapatan
Asli Daerah (PAD) adalah suatu tindakan atau usaha-usaha untuk memperbesar penerimaan dengan cara melakukan pemungutan yang lebih giat, ketat dan teliti. Upaya ini tidak lain dilakukan pemerintah untuk meningkatkan pendapatan asli daerahnya.

Tabel 4.

Realisasi Belanja Kegiatan Intensifikasi dan Realisasi Pendapatan Asli Daerah (PAD) Tahun 2002-2011

\begin{tabular}{|c|c|c|c|c|}
\hline & $\begin{array}{c}\text { Realisasi Belanja } \\
\text { Kegiatan } \\
\text { Intensifikasi }\end{array}$ & $\begin{array}{c}\text { Prosentase (\%) } \\
\text { Bertambah / } \\
\text { (Berkurang) }\end{array}$ & Realisasi PAD & $\begin{array}{c}\text { Prosentase } \\
\text { (\%) } \\
\text { Bertambah / } \\
\text { (Berkurang) }\end{array}$ \\
\hline 2002 & 97.000 .000 & - & 25.750 .017 .455 & Tahun \\
\hline 2003 & 98.000 .000 & 1,03 & 29.488 .458 .866 & 14,52 \\
\hline 2004 & 100.000 .000 & 2,04 & 41.152 .294 .199 & 39,55 \\
\hline 2005 & 110.000 .000 & 10 & 48.242 .903 .314 & 17,23 \\
\hline 2006 & 125.000 .000 & 13,64 & 51.646 .055 .859 & 7,05 \\
\hline 2007 & 128.000 .000 & 2,40 & 55.813 .859 .454 & 8,07 \\
\hline 2008 & 130.000 .000 & 1,56 & 65.108 .137 .872 & 16,65 \\
\hline 2009 & 494.000 .000 & 280 & 74.383 .053 .802 & 14,25 \\
\hline 2010 & 704.041 .208 & 42,52 & 87.321 .034 .057 & 17,39 \\
\hline 2011 & 589.707 .980 & $(16,24)$ & 117.928 .288 .161 & 35,05 \\
\hline Sumber: Dinas Pendapatan Daerah Kota Cimahi (diolah) & & \\
\hline
\end{tabular}


Berdasarkan tabel 4. diatas Pendapatan Asli Daerah (PAD) Kota Cimahi setiap tahunnya mengalami peningkatan, rata-rata sebesar Rp. 59.683.410.304,- atau sebesar 106,78\%, hal ini tidak lepas dari peranan belanja kegiatan intensifikasi. Dengan adanya biaya yang dikeluarkan setiap tahunnya dalam belanja kegiatan intensifikasi diharapkan dapat meningkatkan penerimaan Pendapatan Asli Daerah (PAD) pada Dinas Pendapatan Daerah Kota Cimahi.

Sedangkan untuk jumlah belanja kegiatan intensifikasi, peningkatan pada Tahun 2002 sampai dengan 2010 dengan capaian rata-rata sebesar Rp. 220.671.245,- atau sebesar 44,15\%, dan pada Tahun 2011 jumlah belanja kegiatan intensifikasi terjadi penurunan sebesar Rp. 114.333.228,- atau sebesar 16,24\%, hal tersebut dapat disebabkan adanya efisiensi belanja daerah dalam hal ini belanja kegiatan intensifikasi PAD.
4.2. Penerimaan Pendapatan Asli Daerah (PAD) di Kota Cimahi

Pendapatan Asli Daerah (PAD) bersumber dari pajak daerah, retribusi daerah, hasil pengelolaan kekayaan daerah yang dipisahkan, dan lain-lain Pendapatan Asli Daerah (PAD) yang sah. Di Indonesia permasalahan rendahnya PAD seolah menjadi permasalahan klasik disetiap daerah, oleh karena itu tidak ada satupun Pemerintah Daerah yang benar-benar sanggup membiayai daerahnya sendiri tanpa campur tangan Pemerintah Pusat. Hal ini disebabkan terbatasnya ruang lingkup sumber PAD yang diberikan Pemerintah Pusat.

Selain itu usaha-usaha lain dalam meningkatkan PAD juga penting dilakukan oleh Pemerintah Daerah, baik usaha secara langsung seperti memperbaiki sistem pemungutan PAD dengan cara intensifikasi PAD, maupun usaha tidak langsung seperti meningkatkan kesejahteraan masyarakat.

Tabel 5.

Perkembangan Pendapatan Asli Daerah Kota Cimahi Tahun $2002-2011$

\begin{tabular}{|c|c|c|c|c|c|c|}
\hline \multirow[t]{2}{*}{ No } & \multirow[t]{2}{*}{ Tahun } & \multirow{2}{*}{$\begin{array}{l}\text { Target }(\mathrm{T}) \\
\text { Penerimaan PAD } \\
(\mathrm{Rp.})\end{array}$} & \multirow{2}{*}{$\begin{array}{c}\text { Realisasi(R) } \\
\text { Penerimaan PAD } \\
\text { (Rp.) }\end{array}$} & \multirow[t]{2}{*}{$\mathrm{R} / \mathrm{T}(\%)$} & \multicolumn{2}{|c|}{$\begin{array}{c}\text { Perkembangan } \\
\text { Realisasi Penerimaan } \\
\text { PAD }\end{array}$} \\
\hline & & & & & Jumlah (Rp.) & $\%$ \\
\hline 1 & 2002 & 24.105 .756 .000 & 25.750 .017 .455 & 106,82 & - & - \\
\hline 2 & 2003 & 27.186 .553 .500 & 29.488 .458 .866 & 108,47 & 3.738 .441 .411 & 14,52 \\
\hline 3 & 2004 & 33.176 .396 .531 & 41.152 .294 .199 & 124,04 & 11.663 .835 .332 & 39,55 \\
\hline 4 & 2005 & 43.359 .780 .472 & 48.242 .903 .314 & 111,26 & 7.090 .609 .115 & 17,23 \\
\hline 5 & 2006 & 51.565 .020 .920 & 51.646 .055 .859 & 100,16 & 3.403 .152 .546 & 7,05 \\
\hline 6 & 2007 & 56.033 .235 .423 & 55.813 .859 .454 & 99,61 & 4.167 .803 .595 & 8,07 \\
\hline 7 & 2008 & 62.154 .346 .389 & 65.108 .137 .872 & 104,75 & 9.294 .278 .418 & 16,65 \\
\hline 8 & 2009 & 76.278 .639 .222 & 74.383 .053 .802 & 97,51 & 9.274 .915 .930 & 14,25 \\
\hline 9 & 2010 & 81.594 .254 .429 & 87.321 .034 .057 & 107,02 & 12.937 .980 .255 & 17,39 \\
\hline 10 & 2011 & 109.060 .351 .699 & 117.928 .288 .161 & 108,13 & 30.607 .254 .104 & 35,05 \\
\hline \multicolumn{2}{|c|}{ Rata-rata } & 56.451 .433 .459 & 59.683 .410 .304 & 106,78 & 9.217 .827 .071 & 16,98 \\
\hline
\end{tabular}

Sumber: Dinas Pendapatan Kota Cimahi (diolah)

Selanjutnya dapat disimpulkan dari data tersebut bahwa terdapat kenaikan penerimaan Pendapatan Asli Daerah (PAD) dari tahun ke tahun, namun demikian besarnya kenaikan tersebut dipicu oleh kenaikan target Pendapatan Asli Daerah (PAD) setiap tahunnya. Dari tabel 5. Peningkatan Pendapatan Asli Daerah (PAD) ada yang tidak mencapai target diantaranya tahun 2007 dan 2009, Artinya peningkatan Pendapatan Asli Daerah (PAD) setiap tahunnya belum tentu mencapai maksimum dari target Pendapatan Asli Daerah (PAD).

\subsection{Besar Pengaruh Belanja Kegiatan Intensifikasi Pendapatan Asli Daerah (PAD) terhadap Penerimaan Pendapatan Asli Daerah (PAD) di Dinas Pendapatan Daerah Kota Cimahi}

Belanja kegiatan intensifikasi seperti yang telah di uraikan pada kajian teori, merupakan penurunan kas pemerintah untuk pembayaran suatu tindakan atau usaha-usaha (pemungutan yang lebih giat, ketat dan teliti) dengan tujuan untuk memperbesar penerimaan Pendapatan Asli Daerah (PAD). Berdasarkan teori tersebut, kita akan melihat data yang telah di dapat pada penelitian di Dinas Pendapatan Daerah Kota Cimahi, seberapa besar pengaruh belanja kegiatan intensifikasi Pendapatan Asli Daerah (PAD) terhadap Penerimaan Pendapatan Asli Daerah (PAD) sebagai berikut : 
Tabel 6.

Besar Belanja Kegiatan Intensifikasi PAD dan Penerimaan Pendapatan Asli Daerah (PAD)

\begin{tabular}{|c|c|c|}
\hline Tahun & $\begin{array}{c}\text { Besar Kegiatan Intensifikasi PAD } \\
(\mathbf{R p})\end{array}$ & $\begin{array}{c}\text { Pendapatan Asli Daerah (Rp.) } \\
(\mathbf{X})\end{array}$ \\
\hline 2002 & 97.000 .000 & 25.750 .017 .455 \\
\hline 2003 & 98.000 .000 & 29.488 .458 .866 \\
\hline 2004 & 100.000 .000 & 41.152 .294 .199 \\
\hline 2005 & 110.000 .000 & 48.242 .903 .314 \\
\hline 2006 & 125.000 .000 & 51.646 .055 .859 \\
\hline 2007 & 128.000 .000 & 55.813 .859 .454 \\
\hline 2008 & 130.000 .000 & 65.108 .137 .872 \\
\hline 2009 & 494.000 .000 & 74.383 .053 .802 \\
\hline 2010 & 704.041 .208 & 87.321 .034 .057 \\
\hline 2011 & 589.707 .980 & 117.928 .288 .161 \\
\hline
\end{tabular}

Berdasarkan Tabel 6. belanja kegiatan intensifikasi Pendapatan Asli Daerah (PAD) dan besarnya penerimaan Pendapatan Asli Daerah (PAD) di Kota Cimahi tidak pernah tetap, besarnya selalu bervariatif. Peningkatan belanja kegiatan intensifikasi PAD diimbangi dengan meningkatnya penerimaan PAD di Kota Cimahi. Dilihat dari data tersebut, ada pengaruh belanja kegiatan intensifikasi PAD terhadap penerimaan PAD di Kota Cimahi.

\subsection{Analisis Korelasi}

Dalam penelitian yang penulis lakukan, hanya akan menguji hubungan $X$ dan $Y$ dengan analisis korelasi saja. Karena penelitian ini termasuk dalam sensus, dimana tidak perlu diadakannya uji hipotesis.

Berdasarkan tabel 6. kita dapat melakukan analisis korelasi, kemudian untuk mempermudah mengidentifikasi, kita konversi data dari tabel tersebut ke dalam tabel di bawah ini, selanjutnya dihitung nilai $X^{2}, Y^{2}$, dan $X Y$ nya. Setelah dihitung di masing-masing kolom, nilai $X^{2}, Y^{2}$, dan $X Y$ selanjutnya dijumlahkan dan hasil penjumlahannya disimpan di kolom akhir. Maka untuk lebih jelas perhatikan tabel di bawah ini :

Tabel 7.

Tabel Pembantu Penghitungan Uji Statistik Antara Belanja Kegiatan Intensifikasi PAD dengan PAD di Kota Cimahi Tahun $2002-2011$

\begin{tabular}{|c|c|c|c|c|c|}
\hline Tahun & Ifest & $Y$ & $x^{2}$ & $y^{2}$ & $x y$ \\
\hline 2002 & 97.000 .000 & 25.750 .017 .455 & 9.409 .000 .000 .000 .000 & 663.063 .398 .932 .805 .000 .000 & 2.497 .751 .693 .135 .000 .000 \\
\hline 2003 & 98.000 .000 & 29.488 .458 .866 & 9.604 .000 .000 .000 .000 & 869.569 .206 .318 .313 .000 .000 & 2.889 .868 .968 .868 .000 .000 \\
\hline 2004 & 100.000 .000 & 41.152 .294 .199 & 10.000 .000 .000 .000 .000 & 1.693 .511 .317 .811 .420 .000 .000 & 4.115 .229 .419 .900 .000 .000 \\
\hline 2005 & 110.000 .000 & 48.242 .903 .314 & 12.100 .000 .000 .000 .000 & 2.327 .377 .720 .115 .710 .000 .000 & 5.306 .719 .364 .540 .000 .000 \\
\hline 2006 & 125.000 .000 & 51.646 .055 .859 & 15.625 .000 .000 .000 .000 & 2.667 .315 .085 .790 .950 .000 .000 & 6.455 .756 .982 .375 .000 .000 \\
\hline 2007 & 128.000 .000 & 55.813 .859 .454 & 16.384 .000 .000 .000 .000 & 3.115 .186 .907 .150 .870 .000 .000 & 7.144.174.010.112.000.000 \\
\hline 2008 & 130.000 .000 & 65.108 .137 .872 & 16.900 .000 .000 .000 .000 & 4.239 .069 .617 .159 .360 .000 .000 & 8.464 .057 .923 .360 .000 .000 \\
\hline 2009 & 494.428 .030 & 74.383 .053 .802 & 244.036 .000 .000 .000 .000 & 5.532 .838 .692 .911 .200 .000 .000 & 36.745 .228 .578 .188 .000 .000 \\
\hline 2010 & 704.041 .208 & 87.321 .034 .057 & 495.674 .022 .562 .099 .000 & 7.624 .962 .988 .783 .750 .000 .000 & 61.477 .606 .301 .299 .400 .000 \\
\hline 2011 & 589.707 .980 & 117.928 .288 .161 & 347.755 .501 .675 .680 .000 & 13.907 .081 .148 .583 .900 .000 .000 & 69.543 .252 .596 .281 .200 .000 \\
\hline$\Sigma$ & 2.575 .749 .188 & 596.834 .103 .039 & 1.177 .487 .524 .237 .780 .000 & 42.639 .976 .083 .609 .600 .000 .000 & 204.639 .645 .838 .059 .000 .000 \\
\hline$\Sigma^{2}$ & 6.634 .483 .879 .482 .660 .000 & 356.210 .946 .550 .368 .000 .000 .000 & & & \\
\hline
\end{tabular}

\section{Keterangan : \\ $X \quad$ : Belanja Kegiatan Intensifikasi \\ Y : Pendapatan Asli Daeah (PAD)}

Selanjutnya akan dihitung korelasi dari data yang diperoleh. Berdasarkan data yang diperoleh maka kita dapat menentukan korelasi dengan menggunakan rumus :

$$
r=\frac{n \sum x_{i} y_{i}-\sum x_{i} \sum y_{i}}{\sqrt{\left.\left\{n \sum x_{i}^{2}-\left(\sum x_{i}\right)^{2}\right\} n \sum y_{i}^{2}-\left(\Sigma y_{i}\right)^{2}\right\}}}
$$

Berdasarkan pada tabel 7. kita telah peroleh data perhitungan yang dibutuhkan untuk menjawab rumus korelasi di atas, dan selanjutnya di substitusikan data perhitungan tersebut ke dalam rumusnya, dan diperoleh perhitungan sebagai berikut: 
Berdasarkan pada tabel 7. kita telah peroleh data perhitungan yang dibutuhkan untuk menjawab rumus korelasi di atas, dan selanjutnya di substitusikan data perhitungan tersebut ke dalam rumusnya, dan diperoleh perhitungan sebagai berikut :

$\begin{aligned} r & =\frac{10(204639645838059000000-(2.575749188)(569.834103039}{\sqrt{\{10(1.177 .487 .524237 .780000)-(6.634483879 .482660000)\{10(42639.976083609 .600000000)-(3562109465503680000000000\}}} \\ & =\frac{(2.0463964588380590000000-(1.557 .294956273410000000)}{\sqrt{(5.140391 .362895130000)-(70.1888142857283000000000}} \\ & =\frac{509.101502107 .174000000}{\sqrt{360797.974726280 \times 10^{45}}} \\ & =\frac{509.101502107 .174000000}{600664610848856000000} \\ & =0,847\end{aligned}$

Berdasarkan hasil perhitungan di atas, diperoleh nilai Koefisien Korelasi sebesar 0,847 yang menunjukan bahwa antara variabel $X$ dan variabel $Y$ terdapat hubungan yang sangat kuat (berdasarkan pedoman untuk memberikan interpretasi terhadap koefisien korelasi).

Setelah diketahui besamya Koefisien Korelasi, maka dapat dihitung Koefisien Determinasi yang dipergunakan untuk mengetahui besarnya pengaruh variabel $X$ (Belanja Intensifikasi PAD) terhadap variabel $Y$ (Pendapatan Asli Daerah). Menurut Sudjana (1997:246) rumus Koefisien Determinasi adalah sebagai berikut:

$$
K d=r^{2} \times 100 \%
$$

Berdasarkan kepada rumus tersebut, maka selanjutnya kita tinggal substitusikan saja nilai $r$ (korelasi) yang telah kita hitung sebeulnya ke dalam rumus. Perhitungan Koefisien Determinasinya adalah sebagai berikut:

$K d=r^{2} \times 100 \%$

$K d=(0,847)^{2} \times 100 \%$

$\mathrm{Kd}=71,8 \%$

Dari hasil perhitungan di atas, diperoleh $\mathrm{Kd}$ sebesar 71,8\%, artinya variabel $X$ (Belanja Intensifikasi $P A D)$ mempunyai pengaruh yang "Kuat" terhadap variabel $Y$ (PAD) pada DISPENDA Kota Cimahi sebesar $71,8 \%$, sedangkan sisanya sebesar $28,2 \%$ dipengaruhi oleh faktor lain yang tidak diteliti.

\section{Kesimpulan dan Saran \\ 5.1 Kesimpulan}

Berdasarkan hasil penelitian dan pembahasan maka diperoleh simpulan sebagai berikut :

1. Belanja kegiatan intensifikasi Pendapatan Asli Daerah (PAD) dari tahun ke tahun terus mengalami kenaikan meskipun pada tahun 2011 mengalami penurunan anggaran belanja pada kegiatan intensifikasi, namun. demikian peningkatan belanja kegiatan intensifikasi tersebut diimbangi dengan naiknya penerimaan Pendapatan Asli Daerah di Kota Cimahi, besar persentase (\%) kenaikan belanja intensifikasi PAD terbesar terdapat pada tahun 2009-2010, yaitu sebesar 29,83\%, dan besar belanja intensifikasi Pendapatan Asli Daerah (PAD) yang paling besar terjadi pada tahun 2010 sebesar Rp. 704.041.208,00

2. Besar penerimaan Pendapatan Asli Daerah (PAD) dari tahun ke tahun terus mengalami kenaikan, besar persentase (\%) kenaikan penerimaan PAD terbesar terdapat pada tahun 2010-2011, yaitu sebesar 25,95\%, dan besar penerimaan Pendapatan Asli Daerah (PAD) yang paling besar terjadi pada tahun 2011 yaitu sebesar Rp. 117.928.288.161.

3. Belanja Kegiatan Intensifikasi Pendapatan Asli Daerah (PAD) sangat berpengaruh terhadap peningkatan PAD di Kota Cimahi. Hal ini didukung oleh uji statistik, dimana $r=0,847$ menunjukan adanya korelasi linier antar variabel. Koefisien Determinasinya 71,8\% mengindikasikan bahwa pengaruh $X$ terhadap $Y$ kuat, dimana $71,8 \%$ variasi nilai PAD di Kota Cimahi disebabkan oleh karena adanya perbedaan dalam nilai Belanja Kegiatan Intensifikasi PAD di Kota Cimahi, hal ini menunjukan bahwa ada pengaruh Belanja Kegiatan Intensifikasi PAD terhadap PAD di Kota Cimahi. Sehingga dapat disimpulkan bahwa semakin besar belanja kegiatan intensifikasi Pendapatan Asli Daerah (PAD) yang dikeluarkan maka semakin besar pula penerimaan Pendapatan Asli Daerah (PAD) yang akan diterima.

\subsection{Saran}

Berdasarkan penelitian yang telah dilakukan, maka kiranya dapat diajukan saran-saran yang dapat menjadi masukan bagi Dinas Pendapatan Kota Cimahi. Saran-saran tersebut antara lain:

1. Dengan ditetapkannya Keputusan Walikota No. 973/Kep. 28B-Dispenda/2002 mengenai kegiatan intensifikasi Pendapatan Asli Daerah (PAD) Kota Cimahi, maka Dinas Pendapatan Kota Cimahi harus dapat melaksanakan tugasnya sesuai dengan peraturan yang ada, sehingga dapat menunjang kelancaran kegiatan tersebut dan pada akhirnya dapat meningkatkan penerimaan Pendapatan Asli Daerah (PAD) sesuai dengan yang diharapkan.

2. Dari penelitian diperoleh hubungan yang sangat kuat antara belanja kegiatan intensifikasi Pendapatan Asli Daerah (PAD) terhadap penerimaan Pendapatan Asli Daerah (PAD), maka hal ini harus tetap dipertahankan dengan cara melakukan kontrol terhadap belanja kegiatan intensifikasi Pendapatan Asli Daerah (PAD) karena hal tersebut dapat menunjang besarnya penerimaan Pendapatan Asli Daerah (PAD) Kota Cimahi dan diharapkan semua itu dapat meningkatkan kesejahteraan masyarakat Kota Cimahi. 